\title{
LÓGICA E METAFÍSICA COMO ONTO-TEO-LÓGICA: A LEITURA HEIDEGGERIANA DA CIÊNCIA DA LÓGICA, DE HEGEL
}

\author{
Luciano Campos dos Santos \\ PPGFIL - Unicamp
}

\begin{abstract}
RESUMO: Neste artigo, pretendemos abordar a leitura heideggeriana da Ciência da Lógica, de Hegel, tomando a questão da finitude/infinitude como ponto focal. Para tanto, exporemos, num primeiro momento, a crítica hegeliana ao "pensamento finito" e, em seguida, apresentaremos a "controvérsia" instalada no texto $A$ constituição Onto-teo-lógica da metafísica (1957), buscando mostrar como a tarefa realizada por Heidegger, nesse texto, de marcar a diferença entre o seu pensamento e o de Hegel, tomando por referência a Ciência da Lógica, contribui para a destruição das pretensões infinitistas da metafísica. Entremeando essa abordagem, procuraremos evidenciar também que, não obstante as diferenças dos seus empreendimentos filosóficos, as críticas que Hegel e Heidegger dirigem à tradição metafísica são, em última análise, críticas à linguagem que constitui e regula o discurso dessa tradição.
\end{abstract}

PALAVRAS-CHAVE: Onto-teo-logia, Heidegger, Hegel, Lógica, Metafísica.

ABSTRACT: In this article I intend to approach Heidegger's reading of Hegel's Science of Logic, focusing on the question of the finitude and the infinitude. I shall expose, in a first moment, Hegel's critique of the "finite thinking", and afterwards I shall present the controversy brought forth by The onto-theo-logic consitution of metaphysics (1957): I will try to show how Heidegger's task in this text - to make clear the difference between his and Hegel's thinking, taking the Science of Logic as a refference -, contributes to the destruction of the infinite-like intentions of metaphysics. I shall then try to show, as well, that although their philosophical endeavours are different, the critique that both Hegel and Heidegger direct to the metaphysical tradition are, in fact, a critique of the language which constitutes and regulates the discourse of such tradition.

KEYWORDS: Onto-theo-logy, Heidegger, Hegel, logic, metaphysics. 
"A disputa entre prensadores é a "disputa amorosa" da coisa mesma. Ela ajuda-os alternadamente a penetrar na simples pertença ao mesmo, a partir do qual eles encontram a conveniência no destino do ser (GA 9, p. 336).”

\section{Reabilitação e Destruição da Metafísica - Hegel e Heidegger: dois projetos, duas direções.}

Nos primeiros parágrafos do prefácio à primeira Edição da Ciência da Lógica (1812), Hegel ${ }^{1}$ aponta o desaparecimento da metafísica, sua extirpação, "desde as raízes", do cenário filosófico e cultural do seu tempo, como um fato que manifesta "um singular espetáculo de um povo", que se assemelha "a um templo ricamente ornado, mas desprovido de santuário" (CL, p. 2). A "derrocada” (Untergang) da metafísica, levada a efeito pela filosofia kantiana, e o ideal de uma educação prática - referida à experiência, que "direciona o olhar à necessidade imediata" -, postulado pela moderna pedagogia, representam, lamentavelmente, para Hegel, "a renúncia ao pensar especulativo" e o interdito à possibilidade de o espírito ocupar-se "da sua pura essência" (seinen reinen Wesen). O projeto hegeliano de uma "reforma" (Umgestaltung) da Lógica - impelido pelo movimento do espírito que, tendo mudado sua "forma substancial" na cultura e nas ciências, requer uma consciência à altura dos novos tempos (Cf. CL, p. 34) ${ }^{2}$ - alicerçado no pressuposto da identidade entre ser e pensar ${ }^{3}$, abarca, por conseguinte, a reabilitação da "verdadeira metafísica"

\footnotetext{
${ }^{1}$ Neste trabalho, as referências a Hegel estarão sempre circunscritas ao texto da Ciência da Lógica (CL). As citações desse texto foram traduzidas da versão italiana, de Arturo Moni (tida, por especialistas, inclusive pelo responsável pela versão em espanhol, como uma boa tradução), e cotejadas com o texto original alemão.

2 E a Lógica é exatamente "esta consciência que o espirito tem da sua pura essência" (CL, p. 34).

${ }^{3}$ Esse pressuposto é, na verdade, o resultado da Fenomenologia do Espírito - 0 "puro saber", "o pensar objetivo" (Cf. CL, p. 32; 55ss). Conforme diz Hegel, "A ciência pura pressupõe, por isso, a libertação da oposição da consciência [oposição sujeito-objeto]. Ela contém o pensamento enquanto é, ao mesmo tempo, a coisa em si mesma, ou ainda a coisa em si mesma enquanto é, ao mesmo tempo, também o puro pensamento" (CL, p. 32). ${ }^{4} \mathrm{~A}$ Ciência da Lógica, sendo a exposição das puras formas do pensamento ("puras essencialidades"), que são, a um só tempo, "o essencial das coisas" (cf. CL, p. 17), se "constitui a verdadeira e própria metafísica" (CL, p. 4). Não se pode olvidar, entretanto, que, se Hegel empreende "a reabilitação da Metafísica contra Kant" (Häring apud LEBRUN, 2006, p. 396), não se trata, evidentemente, de recuperar e legitimar a velha metafísica, ao contrário, "o velho discurso sobre o Eu, o Mundo e Deus está para sempre interrompido e seria loucura querer retomá-lo" (LEBRUN, 2006, p. 399). A Metafísica hegeliana é "a pura filosofia especulativa" (CL, p.4), por isso,
} 
Heidegger, em contrapartida, em uma época que se atribuía "o progresso de afirmar novamente a 'metafísica”' (SZ, p. 2), ao levantar a questão do ser (Seinsfrage), tem em vista a destruição ${ }^{5}$ (Destruktion) da história da Ontologia, o que significava, já no projeto de Ser e Tempo, mas, sobretudo, após a virada $(k e h r e)^{6}$, a abertura de um horizonte de pensamento não-metafísico ou pós-metafísico ${ }^{7}$.

Ao realizar as suas respectivas tarefas, ambos os filósofos dão um "passo para trás”, numa incursão pela história da filosofia, assumindo uma particular relação com a tradição: Heidegger, ao propor revolver "a tradição endurecida”, pretende chegar "às experiências originárias, nas quais as primeiras - e daí em diante decisivas - determinações do ser foram obtidas” (SZ, p. 22), e evidenciar os pressupostos ontológicos "não discutidos em princípio” (SZ, p. 89) por essa tradição ${ }^{8}$; Hegel, por seu turno, ao expor o desenvolvimento do pensamento na história da filosofia, irá, conforme observa Lebrun, "envolver a tradição inteira na rubrica do 'pensamento

ao falar de "filosofar metafísico" (cf. CL, p. 126), com essa expressão Hegel quer se referir ao "pensamento finito", incluindo ai a filosofia crítica kantiana.

${ }^{5}$ Não obstante o termo "destruição" (Destruktion) possua, na linguagem comum, uma conotação negativa, Heidegger ressalva que esse termo é por ele tomado no sentido de "delimitar [a Tradição] em suas possibilidades positivas, e isso sempre quer dizer em seus limites" (SZ, p. 22).

${ }^{6}$ É sabido que Heidegger, na carta Sobre o Humanismo, reconhece que o discurso elaborado em Ser e Tempo tem, ainda, resquícios de uma "linguagem da metafísica", e é justamente essa linguagem, da qual Ser e Tempo não consegue desprender-se totalmente, que torna "problemática" e fracassada a Terceira Seção da Primeira Parte (Cf. GA 9, p. 328). Nesse sentido, Pöggeler observa que Ser e Tempo permanece, em certa medida, vinculado ao pensamento metafísico porque "ainda parte - como ontologia fundamental - para um quererfundar". (PÖGGELER, 2001, p. 157).

7 Obviamente, Hegel e Heidegger têm concepções bastante particulares da Metafísica, de modo que, o que ambos entendem por Metafísica não é a mesma coisa. Entretanto, o que aqui queremos enfatizar é o movimento do pensamento de ambos em direções diametralmente opostas: Em Hegel, uma "verdadeira metafísica" só é possivel como exposição do movimento progressivo do pensamento que culmina na "Ideia Absoluta", na qual está sobressumida (aufgehoben) toda a "velha metafísica". Já para Heidegger, uma "superação da metafísica" só é possivel num movimento regressivo - o "passo de volta" (Schritt zurück) - em direção ao "impensado" (Ungedachten) "do qual o pensado [a metafísica] recebe seu espaço essencial [Wesensraum]" (GA 11, p. 57), de tal modo que, "o passo de volta, portanto, move-se fora da metafísica [e] dentro da essência da metafísica [o esquecimento da diferença ontológica]" (GA 11, p. 60).

${ }^{8}$ Note-se que esses objetivos anunciados em Ser e Tempo são, essencialmente, mantidos após a virada, a partir da qual o pensamento de Heidegger se encontra animado pela questão da "Verdade do Ser". Em Tempo e Ser (1962), por exemplo, Heidegger fala, novamente, de "destruição", ao se referir à operação de desmontagem dos sucessivos encobrimentos da destinação inicial do ser como "presença" (Anwesenheit). Embora, a esta altura, Heidegger já esteja se despedindo da própria ideia de "superação" da metafísica, para "abandonar a metafísica a si mesma" (GA 14, p. 30). Sobre A Constituição Onto-teo-lógica da Metafísica como mais uma "estação" de realização da tarefa da "destruição da história da Ontologia", anunciada em Ser e Tempo, ver a Introdução à versão espanhola de Arturo Leyte, p. 24ss. 
finito", não para "opor-se a ela, mas [para] colocar-lhe a questão da sua linguagem” (LEBRUN, 2006, p. 369).

É interessante notar que, não obstante a radical diferença entre os empreendimentos de Hegel e de Heidegger, o pensamento de ambos conflui entre outras coisas - em uma crítica à Lógica Tradicional, à Moderna Filosofia do Conhecimento, ao pensar representativo e à separação sujeitoobjeto. Além disso, tanto para Hegel quanto para Heidegger, a ideia de "finitude" traduz um modo de pensar que, assumido por este e rejeitado por aquele, constitui-se um ponto de referência para as respectivas críticas.

Neste artigo, pretendemos abordar a leitura heideggeriana da Ciência da Lógica, de Hegel, tomando a questão da finitude/infinitude como ponto focal. Para tanto, exporemos, num primeiro momento, a crítica hegeliana ao "pensamento finito" e, em seguida, apresentaremos a "controvérsia" instalada no texto $A$ constituição Onto-teo-lógica da metafísica (1957), no qual Heidegger realiza a tarefa de se medir, explicitamente, com Hegel, e de marcar a diferença entre o seu pensamento e o de Hegel, tomando por referência a Ciência da Lógica. Entremeando essa abordagem e exposição, procuraremos mostrar também como as críticas que Hegel e Heidegger dirigem à tradição são, em última análise, críticas à linguagem que constitui e regula o discurso filosófico dessa tradição.

\section{Filosofia e Finitude: as críticas de Hegel.}

Logo no primeiro prefácio à Ciência da Lógica, Hegel apresenta o Entendimento (Verstand) como uma atividade de conhecimento que, pelo seu modo mesmo de operar, é limitado (finito) e insuficiente para a apreensão do real: "O entendimento", diz Hegel, "determina e tem fixas as suas determinações” (Der Verstand bestimmt und haelt die Bestimmungen fest) (CL, p. 4). As determinações fixas do entendimento têm um caráter meramente abstrato que expressa tão-somente a não-verdade, ou, o que é o mesmo, a irrealidade de tais determinações. Para Hegel, só a Razão primeiramente em um movimento negativo (dialético), mediante o qual "se resolve em nada as determinações do entendimento” (CL, p. 5) e, em seguida, num movimento positivo, que "gera o universal e nele compreende o particular” (CL, p. 5) - pode, efetivamente, conhecer o real, superar a finitude do entendimento e ascender à verdade infinita. 
Mas o que significa, afinal, dizer que as determinações do entendimento são fixas e finitas?

O caráter de fixidez das representações do entendimento pode ser entrevisto no capítulo segundo da Doutrina do Ser, Seção B - A Finitude -, já a partir da contraposição9 entre algo e outro (etwas und Anderes). Apresentados inicialmente como "indiferentes um diante do outro" (CL, p. 118), contendo, assim, "a irrelatividade [Beziehunglosigkeit] da sua determinação: o algo e o outro caem [fallen] um fora do outro” (CL, p. 121). Vale lembrar que, aqui, o algo é um "ente determinado" (Daseiendes) (Cf. CL, p. 116) que, "a bom direito, tem, para a representação, o significado de um real [Reelles]” (CL, p. 116). No desenvolvimento subseqüente dessa contraposição inicial (indiferença e irrelatividade), o algo é tomado "em si contra o seu ser para o outro" (CL, p. 118) e "como referência a si contra a sua referência a outro, como igualdade consigo contra a sua desigualdade. Um tal ser é ser em si" (CL, p. 121, grifo nosso). Ora, tomar algo em sua simples referência a si é tomá-lo abstratamente (Cf. CL, p. 120). Assim, o que caracteriza a fixidez das representações do entendimento é, pois, primeiramente, a irrelatividade dessas representações e, num segundo momento, a simples referência a si, que não é uma reflexividade dialeticamente mediada por um "outro" ${ }^{10}$, mas um em si abstrato", isto é, separado da unidade do ser determinado (na qual está presente também o ser para outro, como momento) e tomado isoladamente ${ }^{12}$.

\footnotetext{
${ }^{9}$ Essa contraposição, num primeiro momento, é apenas uma oposição abstrata e não ainda "a dialética do algo e do outro como reciprocamente limitando-se" (CINGOLI, 1997, p. 168).

${ }^{10} \mathrm{Na}$ relação propriamente dialética, "o algo se conserva no seu não ser [ser outro]; é essencialmente uno com este não ser, e essencialmente não uno com ele. Está, portanto, em relação com o seu ser outro; não é puramente o seu ser outro. $O$ ser outro é ao mesmo tempo contido nele, e ao mesmo tempo ainda dele separado; é ser para outro" (CL, p. 121). Só então, o ser em si e o ser para outro constituem os dois momentos do algo, e a verdade consiste na relação entre eles, manifestada como unidade no algo (Cf. CL, p. 121). Hegel diferencia, no desenvolvimento do ser determinado, o "abstrato Em si", do "em si" como "aquela identidade pela qual aquilo que o algo é em si, está também no algo (nele), ou seja, é isto que o algo é para outro" (MONI, Nota de Rodapé, $\mathrm{CL}$, p. 126): "O em si, no qual algo é refletido em si pelo seu ser para outro, não é mais abstrato Em si, mas como negação do seu ser para o outro é mediado por este, o qual é assim seu momento. Não é somente a imediata identidade de algo consigo, mas aquela identidade pela qual algo é também nele aquilo que este é em si" (CL, p. 126).

11 "Aquela do em si não é senão uma determinação abstrata [abstrakte], e, portanto, ela mesma extrínseca [äußerliche]" (CL, p. 123). "Enquanto algo é em si, é subtraído ao ser outro e ao ser para outro" (CL, p. 122 ).

12 Hegel, na Introdução, assim define o entendimento: "Por entendimento reflexivo deve-se entender em geral o entendimento abstrativo e com isso separador, que persiste nas suas separações" (CL, p. 27). "O pensar abstrato [consiste] no ter firme os conceitos na sua determinidade" (CL, P. 41). Como será mostrado adiante, a fixidez das representações é, portanto, a contra-face da "imediatez da finitude", momento em que a finitude é
} 
O movimento imanente do ser determinado como em si imediato ${ }^{13}$ explicita precisamente o caráter abstrato de tal determinação e, no interior da dialética do algo e outro, em sua negação e limitação recíprocas, aparece o limite (Grenze) como "a mediação pela qual algo e outro tanto é, quanto não ê (CL, p. 133, grifo nosso), tornando-se assim manifesto o caráter imanentemente contraditório do ser determinado (Dasein). Mais adiante, após explicitar o movimento pelo qual o algo tende a ultrapassar o seu limite (Grenze) e ir além de si, Hegel arremata: "O algo, posto com o seu limite (Grenze) imanente como a contradição de si mesmo, da qual é direcionado e expulso além de si, é o finito" (CL, p. 135).

Dizer, portanto, que as determinações do entendimento são finitas significa dizer que elas são constituídas por contradição, pois o finito é "a contradição de si, em si” (CL, p. 145). O apego obstinado (cf. CL, p. 136) do entendimento à finitude impede que este perceba que, "enquanto crê ter alcançado a sua satisfação na conciliação da verdade, se encontra, ao contrário, na inconciliada, ainda aberta, absoluta contradição” (CL, p. 140). O modo como o Entendimento determina o finito e o infinito ilustra exemplarmente a contradição na qual ele se enreda e permanece ao proceder essa determinação:

"Esta contradição se encontra logo nisto: que ao infinito permanece de encontro [gegenüberbleit] o finito como uma existência [e vice-versa] (CL, p. 149).

Assim segregados, finito e infinito são, essencialmente, referidos um ao outro precisamente pela negação que os separa. Esta negação que os refere entre eles [...] é o limite [Grenze] recíproco de um contra o outro (CL, p. 150) [Mas, ao mesmo tempo] $\mathrm{O}$ finito e o infinito - enquanto são assim cada um em si mesmo e na base da sua própria determinação o pôr o próprio outro - são inseparáveis [...] Com isto, é

tomada como absoluta, e compreendida pelo entendimento como "a negação fixada em si [...] a recusa de deixar-se levar afirmativamente ao seu afirmativo, ao infinito, de deixar-se unir com ele" (CL, p.136). Por isso, observa Cingoli (1997, p. 193), "esta acentuação [fixação] da finitude se mostra como consideração unilateral do entendimento, que quer ter firme o finito contra o infinito".

${ }^{13} \mathrm{O}$ movimento que vai do em si abstrato à dialética do algo e outro é assim descrito por Hegel, de modo sumário: "o ser em si é primeiramente relação negativa ao não ser-aí, tem o ser outro fora de si, e está de encontro a ele; enquanto algo é em si, é subtraído ao ser outro e ao ser para outro. Mas, em segundo lugar, tem também em si o não ser, posto que é precisamente o não ser do ser para o outro" (CL, p. 122). 
determinada a forma na qual esta unidade aparece. Posta no ser determinado ou ser-aí, ela é como um mudar [Umschlagen] ou um passar [Übergehen] do finito no infinito e vice-versa, de modo que o infinito no finito e o finito no infinito, o outro no outro, não faça senão evidenciar-se [nur hervortrete], ou seja, que cada um seja um seu próprio imediato nascer no outro, e a relação dos dois seja só uma relação extrínseca (CL, p. 151).”

Ocorre que, nessa operação, própria do entendimento - que consiste em passar (Übergehen) de uma determinação a outra, alternando finito $e$ infinito, infinitamente ("progresso ao infinito" - unendlichen Progresses ${ }^{14}$ ), num ciclo em que cada uma dessas determinações, tomadas irrelativa e independentemente ${ }^{15}$, sai de si, passa pela outra, e apenas retorna a si mesma ${ }^{16}$, perfazendo, assim, uma relação extrínseca e abstrata - já está presente a superação da alternância entre finito e infinito ${ }^{17}$. Qual é, então, o movimento a ser feito pelo pensamento para ascender à verdade do finito e do infinito, já latente nesse "progresso ao infinito" ao qual está preso o entendimento?

Trata-se, apenas, de considerar que, no progresso ao infinito, a determinação do finito e do infinito já encerra a unidade de ambos ${ }^{18}$, pois, se, de um lado, o finito, como “dever ser” (Sollen), ultrapassa (Hinausgehen)

14 "O progresso ao infinito não é, portanto, senão o repetir-se do mesmo, um só e mesmo enfadonho revezamento deste finito e infinito" (CL, p. 153). "Este progresso infinito se apresenta por toda parte onde as determinações relativas são impelidas à sua oposição, de modo que estão em uma unidade inseparável, e não obstante a cada uma é atribuído contra a outra um ser-aí independente. O progresso ao infinito é portanto a contradição que não é desembaraçada, mas sim continua sempre a enunciar só como presente" (CL, p. 152)

15 "Se, por isso, são tomados irrelativamente [beziehungslos], assim a ser somente ligados pela partícula e, então estão um contra o outro como independentes, cada um como aquele que é unicamente em si mesmo [...] Precisamente nisto, que o infinito é assim segregado do finito, e é por isso tornado unilateral, está a sua finitude, e portanto a sua unidade com o finito" (CL, p. 155).

${ }^{16}$ Esse movimento é descrito por Hegel tomando por ponto de partida ora o finito, ora o infinito: "primeiro é 0 finito; depois se ultrapassa o finito, e este negativo ou além do finito é o infinito; em terceiro lugar se ultrapassa, por sua vez, esta negação, e surge um novo termo, surge de novo um finito. [...] 0 mesmo acontece a propósito do infinito ..." (CL, p. 159).

17 "Na acenada alternativa determinação do infinito por meio do finito, e do finito por meio do infinito, está já presente, em si, a verdade tanto de um como do outro deles, e não há senão que acolher no pensamento precisamente aquilo que se tem diante [de si]" (CL, p. 154).

${ }^{18} \mathrm{Na}$ "alternância do finito e do infinito. O finito é só em relação ao dever ser ao infinito, e o infinito é só infinito em relação ao finito. Eles são inseparáveis e, em igual tempo, absolutamente outros um diante do outro. Cada um tem o outro de si em si mesmo. Cada um é assim a unidade de si e do seu outro, e é ser-aí na sua determinação de não ser aquilo que é ele mesmo e que é o seu outro" CL, p. 152). 
o seu limite (Schranke) ${ }^{19}$, nega-o, e torna-se infinito (ruim), do outro lado, o infinito, determinado como algo que é o outro (não-ser) e o limite do finito (a sua negação), é tornado, ele mesmo, finito. Assim diz Hegel: "A infinidade do progresso infinito permanece afetada pelo finito como tal, é limitada por este, e é ela mesma finita. Ora, com isso se teria de fato a unidade do finito e do infinito. Mas a esta unidade não se reflete [Aber auf diese Einheit wird nicht reflektiert]" (CL, p. 153, grifo nosso). É, portanto, necessário "saber aquilo que se diz" (CL, p. 155) com tais determinações. E o que se diz e se põe, no progresso ao infinito, é a unidade irrefletida do finito e do infinito. E, porque irrefletida, tal unidade aparece como uma simples (abstrata) contradição. A alternância da contraposição entre finito e infinito só pode ser percebida e refletida como unidade, quando o pensamento (razão) ultrapassa (supera - aufheben) esse simples passar (Übergehen) de um no outro que é, ele mesmo (o passar), também atividade do pensamento (entendimento) ${ }^{20}$. A superação do passar (do progresso ao infinito), efetuada pela razão, ao perceber a unidade na contradição ${ }^{21}$, é a própria dissolução da contradição que persiste no simples passar (enquanto atividade do entendimento). Assim, aparece então o "infinito afirmativo" (affirmative Unendlichkeit) como a unidade (concreta) do finito e do infinito ruim (agora como momentos). O verdadeiro infinito é determinado,

19 "Como dever ser [Sollen], o algo é portanto elevado além do seu limite [Schranke]" (CL, p. 140) "No dever ser [Sollen] começa o ultrapassamento [Hinausgehen] da finitude, a infinitude" (CL, p. 141).

20 É porque 0 entendimento não ultrapassa 0 simples passar, que não 0 reflete completamente, que Hegel designa o pensar do entendimento como uma "reflexão incompleta [que] tem inteiramente diante de si ambas as determinações do verdadeiro infinito: a oposição do finito e do infinito, e a unidade do finito e do infinito, mas não funde juntos estes dois pensamentos. Um leva consigo inseparavelmente 0 outro, mas aquela reflexão deixa somente que se alternem" (CL, p. 164, grifo nosso). Mais adiante acrescenta: "o simples reconhecer esta sua inseparabilidade significa compreendê-los ou concebê-los. Esta inseparabilidade é o seu conceito" (CL, p. 168). Por isso, Moni, com propriedade, afirma que: "aquilo que o pensamento tem de fazer para proceder além do progresso ao infinito, e assim compreendê-lo e libertar-se também, ao mesmo tempo, de tudo o que este progresso tem para ele de imponente, é simplesmente refletir, ou seja, acolher em si e fazer seu isto que até então havia somente tido diante [de si]. Neste acolher consiste a elevação do infinito da sua simples exterioridade e negatividade, isto é, da forma de um simples progresso, à sua intimidade e verdade, ou seja, à infinidade afirmativa" (MONI in CL, p. 154). Nesse sentido, também afirma Hösle (2008, p. 204): "é verdade que as determinações isoladas não são pensáveis sem a respectivamente outra, portanto são já a unidade dela e de seu outro. Porém, elas são apenas implicitamente essa unidade; essa unidade apresenta-se apenas àquele que desenvolve sua dialética, manifesta-se portanto apenas em um nível mais alto".

21 Precisamente neste ponto temos a diferença essencial entre a reflexão do entendimento e o pensar especulativo: "A natureza do pensar especulativo se mostra aqui como em um completo exemplo na sua forma determinada. Consiste somente no compreender os momentos opostos na sua unidade" (CL, p. 166). "A reflexão incompleta é, por isso, sobretudo, obstinada contra esta unidade" (p. 167). 
primeiramente, como devir (Werden) ${ }^{22}$ e, em seguida, enquanto negação da negação, como um ser-aí (Dasein) que é "presente" (präsent, gegenwärtig), verdadeiramente real (cf. CL, p. 161s).

"Na sua unidade, o infinito e o finito perdem, portanto, a sua natureza qualitativa [pois passam a ser apenas momentos que não "subsistem independentemente"] - reflexão importante, esta, contra a representação que não se quer desapegar, na unidade do infinito e do finito, do hábito de fixá-las naquela qualidade que devem ter, enquanto tomadas separadamente, e que, porém, naquela unidade, vê somente a contradição, e não já também a sua solução por meio da negação da determinação qualitativa. Assim é falseada a primeiramente simples [abstrata] universal unidade do infinito com o finito (CL, p. 156, grifo nosso)."

É necessário, portanto, como exercício de desapego às determinações fixas e contraditórias do entendimento, prestar atenção ao próprio discurso construído pelo entendimento, pois, conforme bem sublinha Cingoli (1997, p. 220), “o problema [ou melhor, a solução], está só no olhar o processo de outro modo”. Nesse sentido, diz Hegel:

"A falsificação que o entendimento empreende com o finito e o infinito, consistente no ter firme como uma diversidade qualitativa a sua relação um com o outro, no afirmá-los na sua determinação como separados, e precisamente como separados de maneira absoluta, se funda sobre o esquecimento daquilo que é para ele mesmo o conceito destes momentos [gründet sich auf das Vergessen dessen, was für ihn selbst der Bregriff dieser Momente ist] (CL, p. 157, grifo nosso).

\footnotetext{
22 "A maneira, portanto, como o infinito é, de fato, é de ser o processo [Prozeß], onde ele se rebaixa a ser somente uma das suas determinações [o infinito ruim], contra o finito (e com isso de ser, ele mesmo, nada além que um dos finitos) e de superar [aufzuheben] esta diferença de si por si mesmo na afirmação de si e de ser, por esta mediação, como verdadeiramente infinito. Esta determinação do verdadeiro infinito não pode ser compreendida [pela razão] na fórmula já acenada da unidade do finito e infinito. A unidade é abstrata igualdade consigo sem movimento, e os momentos são também eles sem movimento. $O$ infinito, ao contrário, como todos os seus dois momentos, é essencialmente só como devir [Werden]" (CL, p. 161).
} 
O entendimento recalcitra tanto contra a unidade do finito e do infinito só porque pressupõe [voraussetz] como persistentes tanto o limite [Schranke] e o finito quanto o ser em si (CL, p. 160, grifo nosso)."

Trata-se, então, de atentar para os pressupostos impensados ${ }^{23}$ do próprio discurso constituído pelo entendimento que, mediante seu modo próprio de pensar, expresso em um modo próprio de dizer - sua gramática ${ }^{24}$ - se enreda e se mantém em contradição ${ }^{25}$. Cabe recordar que, para Hegel,

"as formas do pensamento são, sobretudo, expostas e entregues na linguagem humana [...] em tudo isto que se torna para ele [o homem] um interno, em geral, uma representação, em tudo isso que o homem faz seu, se insinuou a linguagem; e aquilo do que o homem faz linguagem e que ele expressa na linguagem, contém, em uma forma mais involuída e menos pura, ou ainda, do contrário, elaborada, uma categoria (CL, p. 8).”

Assim, a supracitada "questão da linguagem" que, segundo Lebrun, Hegel dirige à Tradição, é precisamente a questão sobre os limites e as possibilidades da gramática que constituiu e regula o discurso das filosofias pretéritas $^{26}$ (cf. LEBRUN, 2006, p. 208, 215). A crítica hegeliana ao pensamento finito não deixa "intacto o Logos tradicional, mas [resulta no] retorno a um 'lógico' livre de todo parti pris, tal que nada mais nos obrigue a dispersar aquilo mesmo que se sabe reunido” (LEBRUN, 2006, p. 218). Fica, então, patente, que a reforma da Lógica, levada a efeito por Hegel, é também a busca de superação da gramática da finitude, restrita aos limites da Lógica

${ }^{23}$ É justamente ao chamar a atenção para aquilo que a representação pressupõe, mas não pensa completamente, que Hegel desmonta o falso problema filosófico que é aquele de "como o infinito sai de si e vem à finitude" (CL, p. 166), que se costuma tomar como embaraçoso e irrespondível. Após desbaratar a questão, Hegel afirma: "não é para responder a essa pergunta, mas antes só para negar os falsos pressupostos que ela contém, vale dizer, a pergunta mesma "(CL, p. 167s, grifo nosso).

24 "Na gramática se refletem, portanto, as estruturas lógicas" (GADAMER, 2000, p. 99).

25 "A contradição pode, assim, consistir apenas em uma desproporção entre o que é pressuposto e o que é explicitamente expresso; isso significa: ela é de natureza pragmática" (HÖSLE, 2008, p. 277).

${ }^{26}$ As filosofias da finitude se enredam em contradições, que não são por elas próprias percebidas, justamente porque se movimentam no âmbito do entendimento. Não por acaso, conforme afirma Hösle (2008, p. 190), "0 método de refutação de Hegel nas preleções no âmbito da História da Filosofia consiste fundamentalmente em demonstrar contradições em seus predecessores". 
formal, isto é, ao modo de pensar do entendimento que, ao fixar-se no vórtice do progresso ao infinito das representações opostas, torna-se incapaz de pensar e afirmar a infinitude verdadeira e o absoluto. É porque a gramática da finitude e a lógica que lhe é inerente só permitem a elaboração de discursos cujos "conceitos são tomados como fixos em uma determinação que os marca de finitude, e os torna incapazes de compreender a verdade, que é em si infinita" (CL, p. 16), que Hegel declarará como a "mais alta tarefa lógica" a de "depurar essas categorias [da lógica formal e natural] [...] e elevar com isso o espírito à liberdade e à verdade” (CL, p. 15, grifo nosso).

Não sem razão, Hegel tem em Kant uma paradigmática filosofia da finitude, contra a qual ele se põe como adversário (cf. CL, p. 47, nota de rodapé). Se, de uma parte, a filosofia transcendental kantiana, no que concerne ao seu idealismo, representou "a mais alta posição que foi adquirida a respeito de si pela consciência de si do espírito” (CL, p. 1), e tem o seu mérito também por reconhecer o caráter intrinsecamente dialético da razão (Cf. CL, p. 40), de outra parte, Kant elogiou e sancionou a completude da Lógica Formal (Cf. CL, p. 34), restringiu ao entendimento a função legítima de conhecimento, e reduziu a realidade passível de ser conhecida ao fenômeno, à "objetividade da aparência” (Cf. CL, p. 40). É tangendo esse fato que Hegel declara:

"Nesta renúncia da razão a si mesma, o conceito da verdade é perdido, a razão é restringida a conhecer somente uma verdade subjetiva, somente a aparência, somente algo ao qual a natureza do objeto mesmo não corresponda. O saber tornou a ser opinião $^{27}$ (CL, p. 27, grifo nosso).

Mas aquela visão cai - enquanto não é conduzida a termo - no erro de crer ser a razão aquela que vem a contradizer-se a si mesma. Ela não percebe que a contradição é precisamente o elevar-se da razão sobre as limitações do entendimento e o resolvê-las [...] A crítica das formas do entendimento levou ao resultado acenado, [a saber] que estas formas não têm nenhuma aplicação às coisas em si. Isto não pode ter outro

27 "A filosofia kantiana é identificada com a ordinária consciência humana, no que se refere à ideia de que 0 objeto é independente e que não se pode chegar ao conhecimento da coisa em si" (CINGOLI, 1997, p. 49). 
sentido senão que tais formas são em si mesmas algo de não verdadeiro (CL, p. 28, grifo nosso).”

É, por conseguinte, contra Kant ${ }^{28}$, que Hegel reabilita a Razão como superior ao Entendimento - precisamente porque destrói a fixidez das suas determinações - e demonstra que a infinitude (como processo) não só é o lugar próprio da verdade como também é a mais elevada realidade, no interior da qual o finito é uma simples e abstrata idealidade ${ }^{29}$ (cf. CL, p. 162s) ${ }^{30}$.

\section{Filosofia e infinitude: as críticas de Heidegger}

De saída, é interessante observar que, assim como para Hegel, também para Heidegger, a filosofia kantiana será uma referência importante como uma filosofia da finitude. No texto Sobre a essência do fundamento (1929), a análise histórico-filosófica do conceito de mundo, realizada por Heidegger, mostra que, justamente em Kant, tal conceito (entendido com uma ideia da razão) aparece como a representação de uma totalidade referida às "coisas finitas subsistentes" 31 , e a finitude aí mencionada, diferentemente da tradição metafísica cristã, não é definida como o caráter daquilo que é criado por Deus, mas

"é explicada tendo em vista que e em que medida as coisas são
objeto possível para um conhecimento finito, isto é, para um
tal [conhecimento] que primeiramente deve deixar dálas
enquanto já subsistentes [vohandene]. Este ente mesmo,
dependente, do ponto de vista de sua acessibilidade, de um

28 "O entendimento que se opõe à razão será identificado por Hegel com a filosofia kantiana" (CINGOLI, 1997, p. 40).

29 "O ideal é o finito assim como está no infinito - a saber, como uma determinação, um conteúdo, que é distinto, mas que porém não subsiste independentemente, mas é como momento" (CL, p. 163).

${ }^{30}$ Embora a infinitude verdadeira seja somente uma categoria da Doutrina do Ser, tal categoria é "uma nova definição do absoluto", que diferentemente das outras formas do ser determinado, faz parte das "séries de determinações que se considera como definições do absoluto" (CL, p. 146), assim, a verdadeira realidade que agora é determinada como infinito verdadeiro, "vem em seguida determinada como essência, conceito, ideia, etc" (CL, p. 162). Hösle lembra que, na Enciclopédia, "o verdadeiro infinito seria 'o conceito fundamental da filosofia"' (p. 196).

31 "Totalidade das condições para um condicionado dado" (GA 9, p. 149). Além dessa concepção de mundo como uma ideia transcendental da razão, Heidegger também observa que, em sua Antropologia do ponto de vista pragmático, Kant entende o próprio homem como um "mundo" e, assim, "mundo" é a "designação para o Dasein humano no núcleo de sua essência” (GA 9, p. 154). 
receptivo aceitar (intuição finita), Kant nomeia de "aparecimentos" [Erscheinungen], isto é, "coisas em aparição". O mesmo ente, entendido, contudo, como possível "objeto" de uma intuição absoluta, isto é, criadora, ele o nomeia de “coisa em si” (GA 9, p.148).”

Em Kant, a finitude diz respeito, primeiramente, às limitações do homem como "ser pensante finito" (cf. CRP, B 72). O entendimento humano é finito porquanto só pode apreender as coisas tais como elas são dadas na nossa receptividade (sensibilidade) e pensadas pela nossa espontaneidade (entendimento), de modo que o conhecimento das coisas tais como elas são em si seria acessível somente a um ente pensante não limitado pelas nossas formas da sensibilidade e do entendimento. Enquanto Hegel vê nessa concepção kantiana a expressão filosófica do apego obstinado do entendimento à finitude, Heidegger vê tal finitude do conhecimento ${ }^{32}$, entendida na chave da finitude da compreensão do ser, como o aspecto constitutivo do ser do homem.

Heidegger também interpreta a filosofia prática kantiana como índice da finitude do homem, contrapondo-se à posição de Cassirer, com o qual debate em Davos, no ano de 1929. Para Heidegger, só um ente constituído essencialmente pela finitude, necessita de algo como uma legislação da Razão sobre o agir, na forma de um imperativo categórico (cf. STEIN, 2001, p. 38s; LOPARIC, 1995, p. 45s $)^{33}$.

Convém, no entanto, observar que, se por um lado, Heidegger e Hegel valoram de modo absolutamente diferente a filosofia kantiana da finitude, por outro lado, Heidegger, como Hegel, enquadrará esta filosofia na rubrica do "pensamento metafísico tradicional".

Avançemos, agora, em direção à crítica heideggeriana - elaborada no texto A Constituição Onto-teo-lógica da metafísica (1957) - da filosofia da

\footnotetext{
32 Heidegger argumenta fortemente a favor da concepção da finitude do homem, tomando por referência a filosofia kantiana, em discussão com Cassirer em torno do texto Kant e o problema da metafísica (cf. STEIN, 2001, p. 38s). Também a respeito deste debate, ainda focando o aspecto teórico, Loparic lembra que, para Heidegger - interpretando Kant -, "a razão dá-se por satisfeita se o seu interesse em determinar a natureza puder ser realizado dentro dos limites da experiência possível. Ainda que venha a estabelecer verdades 'necessárias e universais', estas não transpõem a cesura entre o mundo fenomenal, em princípio cognoscível, e o mundo noumenal, inacessível ao olhar cognitivo, oposição que se constitui um aspecto essencial da finitude teórica do homem" (LOPARIC, 1995, p. 35).

33 "Precisamente o conceito de imperativo categórico enquanto tal mostra a referência a um ser finito" (HEIDEGGER apud STEIN, 2001, p. 39).
} 
infinitude, de Hegel. Esse texto traz, em suas entrelinhas, o reconhecimento do gigantismo de Hegel como pensador ${ }^{34}$. Tal reconhecimento se manifesta, sobretudo, com a auto-imposição da tarefa de se medir, explicitamente, com Hegel. Trava-se, aí, uma verdadeira “ ". Embora as referências de Heidegger a Hegel sejam freqüentes em grande parte de seus escritos, em $A$ Constituição Onto-teo-lógica da metafísica é feita uma exposição sistemática que "reproduz a análise reelaborada em alguns pontos, que encerrou um exercício de seminário do semestre de inverno de 1956/57, sobre a Ciência da Lógica, de Hegel” (STEIN in HEIDEGGER, 1996, p. 171, nota de rodapé). Não se trata, evidentemente, de uma mera exposição das ideias de Hegel, mas de um confronto, da instalação de uma "controvérsia" (Streit). Assim, como é próprio ao seu filosofar, Heidegger enceta um diálogo/discussão com Hegel, com o objetivo de circunscrever o lugar deste na História da Metafísica, vista sob prisma próprio, a saber: como história do esquecimento da "verdade do ser" (Wahrheit des Seins) ${ }^{35}$.

A necessidade, pela qual Heidegger se vê premido, de demarcar os limites que manifestam a diversidade entre o seu pensamento e o de Hegel, se impõe, sobretudo, porque ambos os filósofos, na busca de uma aproximação daquilo que se constituiu, historicamente, como o objeto privilegiado do pensamento filosófico ocidental - o ser -, pensam não somente "o mesmo" (derselben), mas também "da mesma maneira" (in derselben Weise): Ambos pensam o ser ("o mesmo"), historialmente ("do mesmo modo").

A princípio, pode causar uma certa estranheza dizer que Hegel, na Ciência da Lógica, institui o ser como objeto do pensamento. Afinal, o ser é, enquanto pura "imediatez indeterminada" (unbestimmten Unmittelbarkeit), o "começo" (Anfang), o ponto de partida da Ciência, que, segundo Hegel,

\footnotetext{
${ }^{34}$ Em Tempo e Ser (1962), esse reconhecimento é expresso com todas as letras. Lá, diz Heidegger, em referência explícita à Ciência da Lógica, que a dialética especulativa de Hegel é o "pensamento mais poderoso da Modernidade" (GA 14, p. 10).

${ }^{35}$ É importante atentar para esse modo próprio como Heidegger lê a História da Filosofia, que, para ele, a partir de Platão, se confunde com a História da Metafísica. Conforme bem observa Loparic, a leitura que Heidegger faz dos pensadores da tradição não é "nem filológica, nem estruturalista, nem hermenêutica, nem crítica" (LOPARIC, 1995, p. 184). Para Heidegger, todo pensar que desconsidera a questão da "verdade do ser" é já, por isso mesmo, pensar metafísico (Cf. GA 9, p. 321). Assim, o modo próprio de Heidegger dialogar com a tradição filosófica é aquele da "desconstrução" (Abbau), a partir da qual ele aponta a consolidação progressiva do pensar metafísico na história da filosofia ocidental. Essa desconstrução é assim caracterizada por Loparic (1995, p. 188): "desconstruir a metafísica significa mostrar: 1) que representações metafísicas são vazias de conteúdo dado na experiência originária do ser; 2) que os conteúdos que veiculam são encobridores da verdade do ser tal como revelada nessa mesma experiência originária".
} 
tem como objeto, isto sim, o "puro pensamento" (Cf. CL, p. 32) - e disso Heidegger tem plena consciência (cf. GA 11, p. 53). É Heidegger mesmo quem desfaz esse estranhamento ao chamar a atenção para o fato de que o ser é, para Hegel, primeiramente, "imediatez indeterminada", mas também é no ponto de chegada do movimento imanente (dialético-especulativo) do desenvolvimento de suas determinações (exposto pela Ciência) - Ideia Absoluta. A Ideia Absoluta é o ser plenamente determinado. Por isso, dirá Hegel, logo no primeiro parágrafo do capítulo sobre a "Ideia Absoluta", em trecho citado por Heidegger: "Somente a Ideia Absoluta é ser, perene vida, verdade que se sabe a si mesma, e é toda a verdade" 36 . Se, conforme afirma o próprio Hegel, "todas as ulteriores determinações e desenvolvimentos dele [o puro ser - o começo] seriam simplesmente definições mais determinadas e mais ricas" (CL, p. 63), fica patente, assim, que o ser é o objeto da Lógica hegeliana, e, portanto, aquele "mesmo", que "preme o pensamento" (bedrängt das Denken) de ambos os filósofos (cf. GA 11, p. 53).

O outro ponto que se torna importante na controvérsia é, precisamente, "o modo igual" de tratamento do "mesmo". Justamente esse ponto parece estar "na iminência de tornar-se uma pedra no meio do caminho" 37 do pensamento de Heidegger. Trata-se do fato de que "o objeto do pensamento para Hegel é em si historial [geschichtlich]” (GA 11, p. 55), de sorte que o modo de pensar o objeto resulta, também ele, historial - algo que se pode afirmar ipsis verbis do pensamento de Heidegger (cf., p. ex., GA 9, p. 335). Assim, é a mesmidade do objeto e a do modo de pensá-lo que impõem a Heidegger a "obrigação" (gehalten) de evidenciar o diverso, o nãoigual, que se manifesta no "mesmo".

Tal evidenciação do diverso que se manifesta no "mesmo" pretende ser, entretanto, mais que uma tarefa meramente comparativa. $\mathrm{O}$ que mais

\footnotetext{
${ }^{36}$ Vê-se, neste aspecto, que Heidegger compreende bem a Ciência da Lógica, ao chamar a atenção para esse movimento fundamental da Lógica hegeliana, que é o movimento circular. Assim diz Hegel: "a inteira ciência é, em si mesma, uma circulação, na qual o Primeiro se torna também o Último e o Último também o primeiro" (CL, p. 59). Por outro lado, a insistência de Heidegger em interpretar a identificação do começo com o resultado, pensando apenas no resultado da Ciência da Lógica (a Ideia Absoluta), sem sequer fazer menção à sofisticada argumentação de Hegel, na qual ele deriva o "puro ser" do "puro saber" - que é resultado da Fenomenologia do Espirito -, parece ser, antes, uma manobra interpretativa, de Heidegger, para sustentar sua tese sobre a filiação hegeliana à onto-teo-logia. Nesse sentido, fundamental, para Heidegger, será, apenas, chamar a atenção para o fato de que "começo e fim do movimento, e antes disso este [movimento] mesmo, permanece, em toda parte, 0 ser" (GA 11, p. 62).

${ }^{37}$ A expressão é de Stein (in HEIDEGGER, 1996, p. 187).
} 
fundamentalmente deve ser evidenciado na controvérsia (o controvertido por excelência) é, precisamente, a "de-cisão" (Austrag) ${ }^{38}$, a partir da qual o ser se dá e, assim, interpela o pensar e o convoca à "pertença ao mesmo" (Zugehörigkeit zum Selben) (GA 9, p. 336; cf. GA 11, p. 37), constituindo-o, dessarte, como um modo, cada vez diverso, de "correspondência" (Entsprechung) ao "apelo" (Anspruch) do ser (Cf. GA 11, p. 39, 56) ${ }^{39}$ - como um "engajar-se na decisão do ser" (sich auf den Austrag des Sein einlassen) (GA 11, p. 56).

À guisa de "esboço" - e tendo em vista o cerne da controvérsia Heidegger apresenta assim as diferenças de base entre o seu pensamento e o de Hegel: 1) o objeto (Sache) do pensamento hegeliano é o ser absoluto ("conceito absoluto"), enquanto o objeto de seu pensamento é $o$ ser, "sob o ponto de vista de sua diferença com o ente” (GA 11, p. 56); 2) O seu diálogo com a tradição filosófica visa surpreender o "impensado" (Ungedachten) que sustenta o "pensado" (Gedachte), enquanto Hegel evidencia, na história da filosofia, "a força respectiva de cada pensador naquilo pensado por eles, na medida em que, enquanto degrau singular, pode ser sobressumido [aufgehoben] no pensamento absoluto" (GA 11, p. 57); 3) Enquanto Hegel volta-se para as ideias das filosofias pretéritas para indicar a inserção delas no movimento lógico-histórico do pensamento e a sua Aufhebung, ao fim e a cabo, na Verdade e na Ideia Absolutas, Heidegger, por sua vez, concebe o seu diálogo com a tradição ao modo de um "passo de volta" (Schritt zurück) que "aponta para o âmbito a partir do qual a essência da verdade se torna, antes de tudo, digna de ser pensada” (GA 11, p. 58).

\footnotetext{
${ }^{38}$ A Austrag nomeia o modo como o ser se dá, em sua diferença com o ente. A Austrag é o acontecimento que instaura a diferença ontológica.

${ }^{39}$ Costuma-se considerar o Texto Sobre a Essência da Verdade como o "marco inicial" da virada heideggeriana. Já nele, Heidegger esboça a ideia de que o desvelamento do (ser do) "ente em sua totalidade" toca o homem e provoca o pensar, e este se constitui como um "engajar-se" (Sicheinlassen) naquilo que se desvela, tal como se desvela: "o engajar-se no desvelamento do ente não é perder-se nele, mas antes se desdobra em um recuo diante do ente a fim de que este se manifeste naquilo que ele é e como ele é" (GA 9, p. 188s). Mais tarde, Heidegger passará a utilizar sistematicamente o termo "correspondência" (Entsprechung) para referir-se a esse engajar-se do homem (do pensar) com o ser em seu desvelamento. Vale lembrar que a ideia de correspondência ao ser - ao seu "apelo" (Anspruch), à sua "verdade" (Wahrheit), ou ainda, ao seu "destino" (Geschick) - recorrente no Segundo Heidegger -, possui, no contexto dos textos O princípio de Identidade e $A$ Constituição Onto-teo-lógica da Metafisica (ambos de 1957) - que foram reunidos sob o título Identidade e Diferença -, uma especificidade, a saber: a ideia de um comum-pertença (Zusammengehörigkeit) entre ser e pensar, entre ser e homem, no Ereignis (acontecimento-apropriação).
} 
É precisamente o "passo de volta” que torna possível ao pensamento, de modo radical, acessar o âmbito originário a partir do qual dá-se (es gibt) o ser, como ser (horizonte historial de sentido) do ente. Ao buscar surpreender o impensado - a diferença entre ser e ente (diferença ontológica) -, o "passo de volta" direciona-se, assim, para dentro daquilo "a ser pensado [zuDenkende]. Isto é o esquecimento da diferença” (GA 11, p. 59). Heidegger vê no "esquecimento da diferença" a própria origem do pensar filosófico ocidental - o que quer dizer sempre: do pensar metafísico. Para Heidegger, a filosofia sempre se empenhou em pensar o ente, em sua "entidade" (Seiendheit), esquecendo-se, assim, do ser (Cf. Posfácio de Que é Metafísica,) e da diferença, enquanto tal, entre ente e ser. E isto de tal modo que o ser fora sempre confundido com a "entidade" do ente. A filosofia (Metafísica), portanto, pode até começar a partir de um pathos qualquer, mas, origina-se funda-se essencialmente - em um esquecimento primordial que se esquece de si mesmo. Assim, o passo para dentro do "esquecimento da diferença" é, ele mesmo, o passo para "dentro da essência da metafísica” (GA 11, p. 60).

No diálogo/controvérsia com Hegel - cujo fito é pensar como a metafísica se constituiu historicamente como o esquecimento da "essência da verdade”, a partir da qual somente é possível pensar a diferença ontológica -, é a própria experiência do "passo de volta" que dá o tom e indica o rumo. $\mathrm{O}$ ponto de partida é a ideia hegeliana de que Deus "teria o mais incontestável direito" de ser o começo da Ciência (Cf. CL, p. 68; GA 11, p. 62). A pergunta-guia é: "como Deus entra na filosofia?" (GA 11, p. 64). Fundamental, para Heidegger, no entanto, será não simplesmente constatar, mediante pesquisa histórica, que Deus aparece recorrentemente na filosofia como fundamento do ente, mas antes questionar: "De onde se origina a essencial constituição onto-teológica da metafísica?” (GA 11, p. 64).

O diálogo com Hegel, portanto, oferecerá a Heidegger a oportunidade de evidenciar, num caso singular e paradigmático, a estrutura onto-teológica de toda a metafísica. E isso não apenas porque Deus entra pela porta da frente e com todas as honrarias na Ciência da Lógica - uma vez que esta pretende ser, ademais, "a exposição de Deus, como ele é na sua eterna essência antes da criação da natureza e de um espírito finito” (CL, p. 32) mas, principalmente, porque "para Hegel, em verdade, 'a Ciência', isto é, a metafísica, não é 'lógica' porque tem como tema o pensamento, mas antes porque o objeto do pensamento permanece o ser” (GA 11, p. 65). Essa é uma 
tese fundamental de Heidegger sobre a Ciência da Lógica, que não deixa de ser surpreendente e desconcertante. Como Heidegger a sustenta?

A sua argumentação consiste, a princípio, em mostrar que o ser, em Hegel, enquanto Conceito Absoluto ${ }^{40}$ - unidade na qual estão presentes a plenitude e a totalidade das determinações do ser - refere-se ao "ente enquanto tal e no todo" (GA 11, p. 65), de modo que o assunto (Sache) do pensar da Ciência é o ser do ente, em geral e como um todo. Não é o caso de pensar que Heidegger quer aqui expressar, em terminologia própria, a razão porque a Lógica, de Hegel, é também Metafísica. Pois, tal razão reside antes no fato de que, segundo Heidegger, na Ciência da Lógica, o ser - e este é um desdobramento de sua tese básica - "está caracterizado previamente como fundamento; o pensar, no entanto - porque co-pertence ao ser - reúne-se com o ser como fundamento, no modo do aprofundar e fundar" (GA 11, p. 65) ${ }^{41}$.

A tese quer dizer, portanto, que o ser indeterminado, "em sua vacuidade mais vazia, portanto em sua máxima generalidade” (GA 11, p. 65), ao afluir na Ideia Absoluta, se constitui como o "ente como tal e no seu todo", e, desse modo, se "desoculta [entbirgt] como o fundamento [logos] que aprofunda [ergründende] ${ }^{42}$ e que funda [begründende] a si mesmo" (GA 11, p. 65). Assim, é porque o ser é tomado como "fundamento fundante" do ente, como Lógos (no sentido derivado), que a Lógica de Hegel é Metafísica. O pensar metafísico é concebido, por Heidegger, como um fundar que aprofunda fundamentos. É justamente essa busca de fundamentos e, a partir destes, de fundamentações (explicações causais) - a "lógica do lógos" - que abre as portas para que Deus entre na Filosofia. Na busca de fundamentação do ente enquanto tal - o objeto do pensar metafísico -, Deus aparece como o termo último na série das condições para o condicionado (o ente), como próte arkhé, causa prima, e, desse modo, como o fundamentante (Begründende) supremo. Assim, é porque o ser é tomado como fundamento (lógos) do ente (ón), em geral (im Allgemeinen), que a Metafísica (não somente a hegeliana, mas toda a Metafísica) é onto-lógica; e é porque Deus (theós) aparece como o fundamentante (Begründende) supremo (causa prima)

\footnotetext{
40 Segundo Hösle (2008, p. 257), "Hegel não consegue indicar exatamente em nenhum lugar o que propriamente distingue a ideia do conceito", assim, nos referiremos de forma indistinta a conceito absoluto e a ideia absoluta.

${ }^{41}$ No original: "Sein als Grund vorgeprägt ist, das Denken jedoch - dieweilen es mit dem Sein zusammengehört - auf das Sein als Grund sich versammelt in der weise des Ergründens und Begründens".

42 No sentido de que se desenvolve em determinações cada vez mais concretas.
} 
do ente, no todo (im Ganzen), que a Metafísica é Teo-lógica ${ }^{43}$. Lógica, aqui, nomeia "aquele pensamento que, em toda parte, aprofunda e funda o ente enquanto tal e no todo, a partir do ser enquanto fundamento (Lógos)" (GA 11, p. 67). A metafísica, como onto-teo-logia, encerra em si a unidade essencial do fundar e do fundamentar.

Assim, Heidegger chega ao cerne da controvérsia e pode, enfim, asseverar que a origem essencial da constituição onto-teo-lógica da metafísica é aquela Decisão (Austrag) - que perpassa toda a história da metafísica - do ser que se dá (se manifesta) como fundamento (lógos): "A metafísica corresponde [entspricht] ao ser enquanto lógos e é, conforme isto, em sua característica principal, em toda parte lógica” (GA 11, p. 76). Por essa razão, Heidegger diz que Hegel, ao chamar a sua metafísica especulativa de Ciência da Lógica, ao invés de Onto-teo-logia, "traz algo decisivo à tona" (GA 11, p. 65). Esse "algo" é, pois, a vigência da decisão do ser como "fundamento fundante". As sucessivas figuras epocais do ser, presentes na história da metafísica, nada mais são que variações daquela decisão fundamental. $O$ que, entretanto, sempre permaneceu oculto (esquecido) para o próprio pensar metafísico é, justamente, a "decisão enquanto decisão", que, no seu dar-se, instaura a diferença ontológica.

A esta altura, podemos perguntar pela legitimidade dessa leitura heideggeriana da história da metafísica. A intenção de Heidegger de, dando um "passo atrás", adentrar a essência da metafísica, só pode se sustentar na

\footnotetext{
${ }^{43}$ Note-se bem que Deus é, aqui, o nome para aquela "unidade do ente que unifica enquanto fundamento produtor [hervorbringende Grund]" (GA 11, p. 63), "o uno unificante no sentido do supremo" (GA 11, p. 75). É nesse sentido que Heidegger identificará uma onto-teo-logia até mesmo em Nietzche (o elemento teo-lógico seria, precisamente, a ideia do "eterno retorno", e o onto-lógico a "vontade de poder"). Não é o caso, portanto, de se dizer que Heidegger se equivoca ao atribuir à filosofia Antiga uma onto-teo-logia, uma vez que esta só surgiu, efetivamente, na Idade Média, no período escolástico. Heidegger forja sua própria concepção de ontoteo-logia, e é só assim que ele pode dizer que toda a metafísica, o que quer dizer toda a filosofia ocidental, é, essencialmente, onto-teo-lógica. Entretanto, é sempre possível questionar se, na economia interna de determinada filosofia, este ou aquele conceito fundamental exerce, efetivamente, função onto-lógica ou teológica (no sentido dado por Heidegger). Por exemplo: se, por um lado, parece razoável conceder a Heidegger que o eidos, em Platão, é o ser-fundamento do ente (aspecto onto-lógico), ao mesmo tempo em que a ldeia de Bem traduz o aspecto teo-lógico de sua metafísica (ver A Doutrina de Platão Sobre a Verdade), por outro lado, uma onto-teo-logia (em sua unidade essencial) no pensamento de Aristóteles não parece ser facilmente identificável. Segundo Berti (1997, p. 82s), a busca (vã!) de Heidegger pelo significado fundamental que subjaz aos múltiplos significados de ser, em Aristóteles, se dá devido a uma abordagem da ontologia aristotélica, enviesada por uma (má) interpretação escolástica. Da mesma forma que, ainda segundo Berti (p. 83s), seria equívoco interpretar o Primeiro Motor como "causa primeira" do ente enquanto tal - o que exclui, em princípio, a possibilidade que ele seja um "fundamentante supremo". Para maiores detalhes da crítica de Berti à leitura heideggeriana da filosofia aristotélica, ver o capítulo "Heidegger" in Aristóteles no século XX.
} 
medida em que ele puder indicar claramente um âmbito que se situe fora da metafísica, a partir do qual ele fala. Heidegger precisa mostrar que o seu pensar, embora pense o mesmo - o ser -, não o toma como "fundamento fundante". Como Heidegger pensa, então, o ser?

Ser - afirma Heidegger - é sempre "ser do ente", na medida em que é a configuração, sempre epocal, de sentido do ente em geral e em seu todo. Ente, por sua vez, é sempre "ente do ser", porquanto só é o que é na medida em que é iluminado pelo ser que, em suas destinações historiais, lhe confere sentido $^{44}$. Assim, pensar ser, requer, antes de tudo, ater-se à diferença entre ser e ente, ao acontecer dessa diferença, pois "ente e ser já sempre são previamente encontrados a partir da diferença e nela” (GA 11, p. 69). Pensar ser, em sua diferença com o ente, significa, outrossim, pensar o ser, ele mesmo, para além da entidade do ente.

No interior da diferença e a partir dela, o "ser se essencia [west ao modo de uma ultrapassagem para o ente" (GA 11, p. 71) e acontece, assim, como "sobrevinda" (Überkommnis) que "desoculta" (Unverborgen) o ente. Em contrapartida, o ente "aparece ao modo do advento [Ankunft] que se alberga [sich bergenden] no desvelamento [Unverborgenheit]" (GA 11, p. 71). $\mathrm{Na}$ decisão (Austrag) que instaura a diferença, ser e ente se distinguem ao mesmo tempo em que se identificam (cf. GA 11, p. 71). Trata-se, como bem observa Stein (in HEIDEGGER, 1996, p. 196, nota do tradutor), de uma "identidade dinâmica", mediante a qual o ser, em sua transitividade, torna-se ser do ente, sem confundir-se com o ente. A origem essencial da decisão a partir da qual o ser aparece sempre como "sobrevinda" e "desvelamento" que põe o ente em manifesto - o desoculta e o alberga no seu estar desoculto e, desse modo, dele se diferencia - é Acontecimento (Ereignis) indisponível ao pensar representativo da metafísica.

Ao pensar o ser como "sobrevinda desencobridora" (entbergende Überkommnis) e o ente como "advento que se alberga no desvelamento", Heidegger prossegue, assim, o seu intento de superação do pensar metafísico, mediante o desenvolvimento da questão da "verdade do ser", posta nestes termos a partir dos anos 30. A questão da verdade do ser põe em marcha o "pensar no próprio ser" (GA 9, p. 368 ) - em seu acontecer historial, isto é, o pensar o ser enquanto "destino [Geschick] que destina verdade" (GA 9, p.

\footnotetext{
44 "Sem o ser, ente algum como tal é capaz de ser" (GA 14, p. 26). "Para toda percepção do ente em seu ser, ser mesmo já se iluminou e acontece [ereignef] em sua verdade" (GA 9, p. 323).
} 
339). Esse pensar, ao penetrar o solo essencial no qual a metafísica finca suas raízes (cf. GA 9, p. 365), situa-se, sem sombra de dúvidas, num âmbito outro que aquele da metafísica, que se atém sempre a pensar o ente enquanto ente. O pensar a verdade do ser é uma correspondência ao ser enquanto ser, não ao ser como "fundamento fundante", por isso, "no pensamento da verdade do ser, a metafísica [já] está superada” (GA 9, p. 367). O texto $A$ Constituição Onto-teo-lógica da Metafísica, juntamente com O Princípio da Identidade, é mais um passo na marcha desse pensar. Nele, o pensar do ser vai além do próprio ser e ascende ao Acontecimento (Ereignis) doador do ser.

A tarefa de superar a metafísica sempre se deparou, desde os seus primeiros passos, esboçados em Ser e Tempo, com uma dificuldade de princípio, a saber: a linguagem. $\mathrm{O}$ próprio Heidegger refere-se à dificuldade do seu pensamento em realizar a virada (Kehre), ainda em Ser e Tempo (tratase da Terceira Seção da Primeira Parte), como "fracasso" de um "dizer", de uma linguagem que, ainda vinculada à metafísica (cf. GA 9, p. 328), foi incapaz de articular adequadamente Tempo e Ser. Para Heidegger, assim como para Hegel, há uma íntima e inelidível vinculação entre linguagem e pensamento, de tal modo que os limites e possibilidades de uma linguagem são também limites e possibilidades do pensamento, e vice-versa. Heidegger esposa a ideia de que as palavras sempre reverberam um modo de pensar, que, por sua vez, é sempre correspondência ao modo como o ser se dá: "no pensar, o ser vem à linguagem” (GA 9, p. 313) ${ }^{45}$. São sobejamente conhecidas as violentadoras interpretações que Heidegger faz das palavras da tradição, para fazê-las expressar o pensamento que nelas se esconde e que as forjou, a partir de uma determinada correspondência ao ser. Assim, o pensar que faz uma experiência da tradição, a partir do impensado, do não-dito, só pode exprimir-se de modo titubeante e, amiúde, incompreensível para o pensar representativo ${ }^{46}$, posto que uma gramática não metafísica não apenas não está previamente disponível ${ }^{47}$, como sequer sua possibilidade está

\footnotetext{
45 "A linguagem é a casa do ser" (GA 9, p. 313). "A linguagem é advento iluminador-velador do próprio ser" (GA 11, p. 326)

${ }^{46} \mathrm{O}$ próprio Heidegger é consciente da possibilidade, sempre à espreita, de estranhamento de sua linguagem e não-compreensão de suas ideias, possibilidade esta que, frequentemente, se transforma objeções e rejeições. Particularmente interessante, nesse sentido, é a "carta a um jovem estudante" - em resposta a questionamentos feitos sobre a conferência $A$ Coisa -, na qual se refere à forma como seus discursos são comumente recebidos, a saber: "como arbitrários e desordenados" (GA 7, p. 187).

${ }^{47}$ A ausência de uma "gramática" para o tratamento da questão do ser era já sentida em Ser e Tempo (cf. SZ, p. 39).
} 
assegurada ${ }^{48}$. "Decisão", "Sobrevinda” e "Advento"49 são, portanto, palavras (entre tantas outras bem conhecidas) que, à medida que se inscrevem no interior de um projeto de superação da metafísica, convidam a pensar nãometafisicamente ${ }^{50}$. Assim, a tarefa da superação do pensar metafísico é sempre, a um só tempo, uma crítica (destruição) do léxico, da sintaxe e da semântica que constitui o discurso que configura esse pensar - uma crítica que demarca as possibilidades e os limites da linguagem metafísica, cujo "resultado" pode ser assim sumariamente descrito: a linguagem metafísica limita-se à verdade do ente, e é incapaz de dizer a verdade do ser.

É situando-se, portanto, fora da metafísica assim caracterizada, que Heidegger pode arrematar a sua leitura da Ciência da Lógica, evidenciando como se constitui o pensar em geral, ao mesmo tempo em que enfatiza a especificidade do seu próprio pensar, enquanto tentativa de superação da metafísica. Assim diz ele:

"o ser se dá também aqui [em Hegel] apenas na luz que se iluminou para o pensar de Hegel. Isto quer dizer: como ele, o ser, se dá, sempre se determina por si próprio a partir do modo como se ilumina [es sich lichtet]. Este modo é, entretanto, um [modo] destinado, uma cunhagem sempre epocal [...] Somente atingimos a proximidade do [que é] destinado, através do súbito instante de uma lembrança. Isto vale também para a experiência de cada cunhagem da diferença de ser e ente, à qual corresponde uma respectiva interpretação do ente enquanto tal. $\mathrm{O}$ que foi dito vale antes de tudo também para nossa tentativa de, no passo de volta do esquecimento da diferença enquanto tal, pensar nela enquanto decisão de sobrevinda desencobridora e advento que se alberga (GA 11, p. 73)."

\footnotetext{
${ }^{48}$ Heidegger mesmo deixa aberta a questão "se a essência das línguas ocidentais é em si mesma meramente metafísica e, portanto, caracterizada em definitivo pela onto-teo-lógica, ou se essas línguas garantem outras possibilidades de dizer, isto é, ao mesmo tempo, do não-dizer que diz" (GA 11, p. 79).

49 "o que assim é dito remete nosso pensamento para o âmbito não mais adequado ao dizer das palavras-guias da metafísica: ser e ente, fundamento-fundado. Pois o que essas palavras nomeiam, o que representa o modo de pensar por elas conduzido, surge como o diferente, a partir da diferença. Sua proveniência não se deixa mais pensar [e dizer] no horizonte da metafísica" (GA 11, p. 77)

50 "neste falar sobre decisão, já deixamos vir à palavra aquilo que foi e continua sendo [das Gewesene], na medida em que nós pensamos em um desencobrir e um encobrir, uma ultrapassagem (transcendência) e um advento (presença)" (GA 11, p. 73).
} 
O que Heidegger aqui põe em jogo é, mais uma vez, a ideia de que o pensar é sempre "correspondência" (Entsprechung) ao ser que se dá, como destino imprevisível e incontrolável, "sempre com este ou aquele cunho historial: physis, lógos, hén, idéa, enérgeia...” (GA 11, p. 73). Esses "nomes do ser” traduzem o modo como o ser se dá no tempo (história), o modo específico de seu desvelar-se. O ser "dá-se” (es gibt sich) significa sempre: ele se mostra como uma configuração de sentido do ente enquanto tal e no todo $^{51}$, sentido esse recolhido na abertura (o "aí") que constitui essencialmente o homem. A história da metafísica é, a um só tempo, a história da correspondência e lembrança do ser como fundamento e "presença" (cf. Tempo e Ser), e história do esquecimento do ser enquanto darse de uma decisão, enquanto diferença, desvelamento, abertura, verdade, destino e clareira que possibilita que o ente seja o que é $e^{52}$. Essa história, no entanto, é ela própria um destino do ser que, à medida que se dá, também se ausenta, se recusa (versagt), se retira (vorenthält), se retrai (entzicht) e, assim, produz o seu próprio esquecimento (cf. GA 7, p. 134).

Destarte, ao caracterizar a Lógica de Hegel como onto-teo-lógica e evidenciar a sua origem impensada no esquecimento da verdade do ser e da diferença ontológica, o que Heidegger faz é, justamente, mostrar que a metafísica especulativa hegeliana não é outra coisa senão a atualização daquela decisão originária da história da metafísica, a saber: a do ser que, ocultando-se enquanto ser, ele mesmo, dá-se como fundamento fundante do ente. Em suas referências a Hegel, Heidegger preocupa-se constantemente em lembrar o caráter relativo e finito do Absoluto hegeliano: "Também aí, onde, como em Hegel, um [presente, Anwesende] se reflete no outro especulativamente, aí já impera abertura [...] Apenas essa abertura garante também primeiramente ao curso do pensamento especulativo sua passagem através daquilo que ele pensa” (GA 14, p. 80). O pensar hegeliano é, portanto, segundo Heidegger, apenas um modo específico de correspondência ao ser (cf. GA 14, p. 13) que, embora se dê - na clareira/abertura na qual se move o

\footnotetext{
51 Sobre a relação entre "Sentido do Ser" e "Verdade do Ser" ver O retorno ao fundamento da metafísica Introdução de Que é metafísica.

52 O ser é a clareira [Lichtung] do ente (Cf. GA 9, p. 337), no sentido de que é a "abertura que garante um possível deixar-aparecer [Scheinenlassen] e um mostrar [os entes]" (GA 14, p. 80).
} 
pensamento especulativo - como Ser Absoluto e Processo Infinito, é, ele mesmo, finito, porquanto entregue ao "aí" do homem (cf. GA 9, p. 120). ${ }^{53}$

O pensar que atenta para o "esquecimento da diferença", por meio do "passo de volta", é, por isso mesmo, apenas "lembrança” (Andenken). Uma lembrança que só é possível a partir de uma atitude de escuta do pensamento ao apelo do "ser como ser" (cf. GA 11, p. 70; Sobre o Humanismo, passim). É um pensar que - enquanto lembrança (Andenken), questão (Frage), debate (Streit), caminho (Weg), escuta (hören), diálogo (Gespräch), indicação (Anzeige) - recusa "explicações e fundamentações" e se põe "na descida para a pobreza de sua essência provisória” (GA 9, p. 364).

Assim, se Deus entra para a filosofia "a partir da essência da metafísica" (GA 11, p. 77), o pensar que lembra o esquecimento da diferença e, desse modo, tenciona superar a metafísica, é e deve ser um "pensamento ateu [gott-lose], que deve abandonar o Deus da filosofia” (GA 9, p. 199). Ora, abandonar o Deus-fundamentante-supremo é, outrossim, renunciar à infinitude como conceito filosófico central. O pensamento que se move no âmbito do questionamento da verdade do ser concebe a finitude como o lugar próprio do ser e da verdade.

\section{Referências Bibliográficas}

BERTI, E. Aristóteles no século XX. São Paulo: Loyola, 1997.

CINGOLI, M. La qualità nella scienza della lógica di Hegel: commento al libro I, sezione I. Milano: Edizioni Angelo Guerini e Associati, 1997.

FOUCAULT, M. A ordem do Discurso (Tradução de Laura Fraga de Almeida Sampaio). 8.ed. São Paulo: Loyola, 2002.

GADAMER, H.-G. La dialéctica de Hegel: cinco ensayos hermenêuticos. Traducción de Manuel Garrido. 5 .d. Madrid: Ediciones Cátedra, 2000. HEGEL, G. G. F. La scienza della lógica (CL) (Traduzione con note di Arturo Moni). Volume Primo. Bari: Gius. Laterza \& Figli, 1924.

53 Cabe aqui uma observação/inquietação: os esforços de Heidegger em se distanciar, explícita e sistematicamente, de Hegel, parecem, sobretudo, revelar a consciência de uma ameaçadora proximidade. Assim, vale especialmente para o pensamento de Heidegger o que Foucault diz, a propósito de Nietzsche, Marx e outros, em A Ordem do Discurso: "Escapar realmente de Hegel supõe apreciar exatamente o quanto custa separar-se dele; supõe saber até onde Hegel, insidiosamente, talvez, aproximou-se de nós; supõe saber, naquilo que nos permite pensar contra Hegel, o que ainda é hegeliano; e medir em que nosso recurso contra ele é ainda, talvez, um ardil que ele nos opõe, ao termo do qual nos espera, imóvel e em outro lugar". (FOUCAULT, 2002, p. 72s). 
. Wissenschaft der Logik. Erstes Buch. In: Gesammelte Werke. v. 21. Meiner: Hamburg, 1984.

HEIDEGGER, M. Sein und Zeit. Tübingen: Max Niemeyer Verlag, 1967.

Gesamtausgabe: Band 7: Vorträge und Aufsätze. Frankfurt/M:

Vittorio Klostermann, 2000.

- Gesamtausgabe Band 9: Wegmarken. Frankfurt/M: Vittorio Klostermann, 1976.

. Gesamtausgabe Band 11: Identität und Diferenz. Frankfurt/M: Vittorio Klostermann, 2006.

. Gesamtausgabe. Band 14: Zur Sache des Denkes. Frankfurt/M: Vittorio Klostermann, 2007.

- Conferências e Escritos Filosóficos (Tradução e notas de Ernildo Stein). São Paulo: Nova Cultural, 1996. Coleção Os Pensadores.

. Ensaios e conferências (Tradução de Emmanuel Carneiro Leão, Gilvan Fogel, Márcia de Sá Cavalcante Schuback). 3.ed. Petrópolis: Vozes; Bragança Paulista: Editora Universitária São Francisco, 2006.

HÖSLE, V. O sistema hegeliano: o idealismo da subjetividade e o problema da intersubjetividade. Belo Horizonte: Loyola, 2008.

KANT, I. Crítica da razão pura (CRP) (Tradução de Manuela Pinto dos Santos e Alexandre Fradique Morujão). 5.ed. Lisboa: Fundação Calouste Gulbenkian, 2001.

LEBRUN, G. A paciência do conceito. São Paulo: UNESP, 2006.

LOPARIC, Z. Ética e finitude. São Paulo: EDUC, 1995.

. "Descartes Desconstruído". Cadernos de História e Filosofia da

Ciência. Campinas, SP, v. 5, n. 1-2, p. 183-203, jan.-dez. 1995

PÖGGELER, O. A via do pensamento de Martin Heidegger. Lisboa: Instituto Piaget, 2001.

STEIN, E. Compreensão e finitude estrutura e movimento da interrogação heideggeriana. Ijuí: Ed. Unijuí, 2001. 